\title{
The effect of sub-lethal doses of Azadirachta indica (Meliaceae) oil on the midgut of Spodoptera frugiperda (Lepidoptera, Noctuidae) ${ }^{1}$
}

\author{
Antonia Railda Roel ${ }^{1,2}$, Doroty M. Dourado ${ }^{1,4}$, Rosemary Matias ${ }^{1,4}$, Karla R. A. Porto ${ }^{1}$, \\ Aline V. Bednaski ${ }^{1,4} \&$ Reginaldo B. da Costa ${ }^{3}$
}

${ }^{1}$ Rede Bioprospecção do Centro de Pesquisas do Pantanal, Rua Nove 305, 78068-410 Cuiabá-MT, Brazil.

${ }^{2}$ Master of Biotechnology Program - The Dom Bosco Catholic University (UCDB), Avenida Tamandaré 6000, 79117-900 Campo Grande-MS, Brazil. arroel@ ucdb.br

${ }^{3}$ The Forestry and Environmental Sciences Program - The Federal University of Mato Grosso (UFMT), Avenida Fernando Corrêa da Costa s/n, 78060-900 Cuiabá-MT, Brazil. reg.brito.costa@gmail.com.br

${ }^{4}$ The Tissue Research Laboratory - The University for the Regional Development of the Pantanal (UNIDERP), Rua Alexandre Herculano 1400, 79037-280 Campo Grande-MS, Brazil. douradod@uol.com.br

\begin{abstract}
The effect of sub-lethal doses of Azadirachta indica (Meliaceae) oil on the midgut of Spodoptera frugiperda (Lepidoptera, Noctuidae). The fall armyworm, Spodoptera frugiperda, is one of the major field pests for maize production. It is mainly controlled by means of synthetic, and more recently by resistant cultivar of maize expressing Bt toxins. The neem tree, Azadirachta indica, is a plant that can potentially control insects with the advantage of being food and environmental safe. The aim of this study was to assess the effect of neem oil on the development and survival of $S$. frugiperda caterpillars by assessing histological alterations caused on their midgut. Newly hatched caterpillars were submitted to three neem oil concentrations: 0.006; $0.05 ; 0.4 \%$, which were added to their artificial diet. Ten $3^{\text {rd }}$ instar caterpillars, taken from each treatment, were submitted to histological analysis. The alimentary canals from the specimens were fixed in Baker for 12 hours, desiccated and diaphanized in alcohol/xylol (1:1) and xylol. After placing the samples in paraffin, they were sliced in $8 \mu \mathrm{m}$ sections and stained with hematoxylineosin stain. The neem oil added to the diet of $S$. frugiperda caused total mortality at dose of $0.4 \%$ whilst still in the first instars, prolonged the larval and pupal stages, and reduced the pupal weight. Histo-physiological alterations such as degeneration of the epithelial lining of the midgut and in the peritrophic matrix were found at all concentrations of neem oil.
\end{abstract}

KEYWORDS. Fall armyworm; histological analysis; insecticidal plants; neem.

RESUMO. Efeito de doses subletais do óleo de Azadirachta indica (Meliaceae) no mesêntero de Spodoptera frugiperda (J. E. Smith) (Lepidoptera, Noctuidae). A lagarta-do-cartucho, Spodoptera frugiperda, é a mais importante praga da cultura do milho. Esta é usualmente, controlada por inseticidas sintéticos e mais atualmente por meio de variedades resistentes de milho com a toxina Bt. O nim Azadirachta indica é planta com potencial no controle de insetos, que possui as vantagens de segurança alimentar e ambiental. Objetivou-se com este estudo avaliar o efeito do óleo do nim no desenvolvimento e sobrevivência de lagartas de $S$. frugiperda em decorrência das alterações no mesêntero. As lagartas recém nascidas foram submetidas a três concentrações do óleo de nim: 0,$006 ; 0,05 ; 0,4 \%$, adicionadas à dieta artificial. Dez lagartas do $3^{\circ}$ instar, retiradas de cada tratamento, foram submetidas à análise histológica. O canal alimentar dos indivíduos foi fixado em Baker por 12 horas, desidratado, diafanizado em álcool/xilol (1:1) e xilol. Após a inclusão em parafina, as amostras foram seccionadas em $8 \mu \mathrm{m}$ e coradas pela técnica de hematoxilina-eosina. Observou-se que o óleo de $A$. indica adicionado à dieta de $S$. frugiperda causa: mortalidade total na dosagem $0,4 \%$ nos primeiros instares, aumento na duração do período larval e pupal, redução no peso de pupas. Alterações histofisiológicas, como degeneração do epitélio do revestimento do mesêntero, da matriz peritrófica foram registradas em todas as concentrações do óleo de neem.

PALAVRAS-CHAVE. Análise histológica; lagarta-do-cartucho; nim; plantas inseticidas.

Among the most significant corn pests is the fall armyworm, Spodoptera frugiperda (J. E. Smith, 1797) (Lepidoptera, Noctuidae) which under favorable climatic conditions, has a high reproduction potential leading to rapid population increase. The feeling by these insects causes damage to the leaves and ears reducing plant development and, consequently, grain production. The fall armyworm is mainly controlled by synthetic insecticides, which are not always efficient, and more recently by resistant cultivar of maize expressing Bt toxins (Waquil et al. 2002).

The use of plants as insecticides is not a recent pest control technique since this was commonly used in tropical countries before the advent of synthetic insecticides. The application of substances with insecticidal action extracted from plants has some advantages when compared with synthetic substances: they are easily degradable, that is, they do not remain in the environment and leave no residues in food products (Vendramim \& Castiglioni 2000).

The neem tree, Azadirachta indica A. Juss (Meliaceae), has been known for thousands of years due to its antiseptical properties (Mossini \& Kemmelmeir 2005). It has adverse effects on more than 430 insect pest species of in several countries. It causes effects such as repellence, halting of development and ecdysis, development delay, fertility and fecundity reduction, behavioral and physiological changes leading to possible mortality. Other effects can occur on the hormonal system causing developmental disturbances, deformations and even infertility. The extent of the effects 
and reaction time are always a function of the dosage used and the time of exposure (Martinez 2002).

Neem is considered to have low toxicity for mammals, and it is efficient even in low concentrations. Like other active plant molecules, there is a lower probability of resistance development due to the complexity of its active components (Vendramim \& Castiglioni 2000).

Many experiments on neem derivatives have shown its insecticidal potential on the fall armyworm with results similar to those obtained with synthetic products (Maredia et al. 1992; Martinez 2002; Prates et al. 2003; Viana \& Prates 2003).

However, the verification of the location and form of action on the insect has great importance for the development of an efficient and safe insecticide (Barreto et al. 2006). Therefore, morphological studies are an important tool when trying to understand the form of action of natural products (Dequech et al. 2007). The deleterious physiological effects can be measured by growth reduction and presence of abnormalities (Mordue \& Nisbet 2000).

The midgut is the middle portion of the insect digestive tract where food digestion and absorption occur. Some epithelium cells produce enzymes and others absorb the digested food (Borror \& Delong 1969; Terra \& Ferreira 1994). Since most nutrient absorption occurs in this region the cellular modifications are more intense here since the digestive process is intensified in the midgut.

The insect midgut is generally endowed with columnar or cylindrical cells, which are responsible for enzyme secretion and absorption. Regenerative cells, which may be intercalated with the columnar cells, have the function of regenerating epithelium cells regularly destroyed by secretion release during the moulting process. The midgut also has caliciform cells, the function of which is uncertain. These cells are well developed in Lepidoptera (Buzzi 2002). Cavalcante \& CruzLandim (1999), when mentioning the insect midgut, state that the caliciform cells are responsible for the production of digestive enzymes. The cylindrical cells, or absorption cells, have microvilosities, which increase the absorption capacity of the digested food.

The aim of this study was to verify histomorphological alterations in the midgut of $S$. frugiperda, the mortality, the duration of larval and pupal stages, and pupal weight, caused by neem oil added to the artificial diet with sub-lethal doses.

\section{MATERIAL AND METHODS}

The research was conducted in the Entomology laboratories of the Dom Bosco Catholic University (UCDB) and in the laboratory of Tissue Research at the University for the Regional Development of the Pantanal (UNIDERP), Campo Grande, MS, from July 2007 to July 2008.

The $S$. frugiperda caterpillars were obtained from breeding stock fed with the Greene et al. (1976) artificial diet. The experiment was conducted in a climate-controlled chamber (BOD) where the temperature was maintained at $26 \pm 1^{\circ} \mathrm{C}$, UR $70 \pm 15 \%$ and photophase of 14 hours.

Biological assay. The new hatched caterpillars were placed individual diet tubes $(8 \times 2.5 \mathrm{~cm})$ and fed on artificial diet. The treatment, three concentration levels of neem oil $A$. indica, was added to the diets at concentration levels of $0.006,0.05,0.4 \%$, using 50 caterpillars, for each treatment level. The following biological parameters were assessed: duration and viability of the larval and pupal stages, pupa weight after 24 hours.

Histological analysis. For the histological analysis, 10 caterpillars in the $3^{\text {rd }}$ and $4^{\text {th }}$ instars were removed from the experiment from each concentration level. For dissection, the caterpillars were anaesthetized in ethyl ether $(1: 1)$ and the samples of the alimentary canal were removed and fixed in Baker, for 12 hours. Following this they were desiccated and diaphanized in alcohol/xylol (1:1) and xilol (Michalany 1980). After placing in paraffin, the samples were sliced in 8 $\mu \mathrm{m}$ sections and stained with hematoxylin-eosin stain (Luna 1968, modified). Morphological alterations of the midgut cell structure and organization of each caterpillar were analyzed and compared to the tissues taken from the control group (Pearse 1968). Pictures were taken using a "Carl Zeiss" photomicroscope coupled to a "Samsung" micro-camera connected to a computer fitted with an image capture card and IMAGELAB software.

Statistical analysis. The statistical analysis of the duration of larval and pupal stages and the pupa weight data used the ANOVA method followed by multiple comparisons of means using the Tukey test. The results were expressed as mean \pm mean standard deviation.

\section{RESULTS AND DISCUSSION}

Biological parameters. The assessments carried out during the larval development stages showed that the treatment with the artificial diet with neem oil at concentration level of $0.4 \%$ resulted in $100 \%$ mortality, none caterpillars reached pupa stage. Maredia et al. (1992) also obtained 100\% mortality of $S$. frugiperda treated with $5 \mathrm{~g} \mathrm{~kg}^{-1}$ of neem seed powder.

At the lower concentration levels, 0.05 and $0.006 \%$, the mortality rate was $12 \%$ and $44 \%$, respectively, in relation to the control (6\%) (Table I).

The caterpillars on the artificial diet with neem oil at $0.006 \%$ and $0.05 \%$ that completed the larval development stage had a significantly longer development period than

Table I. Duration of the larval and pupal stages of Spodoptera frugiperda reared on artificial diet with Azadiracta indica oil at different concentration levels, at $26 \pm 1^{\circ} \mathrm{C}$ and 14 hours photophase.

\begin{tabular}{lcccc}
\hline Treatment & $\begin{array}{c}\text { Larval } \\
\text { duration* } \\
\text { (days) }\end{array}$ & $\begin{array}{c}\text { Pupal } \\
\text { duration* } \\
\text { (days) }\end{array}$ & $\begin{array}{c}\text { Pupa } \\
\text { weight* } \\
(\mathrm{g})\end{array}$ & $\begin{array}{c}\text { Larval } \\
\text { mortality } \\
(\%)\end{array}$ \\
\hline Control & $21.12 \pm 0.20$ a & $11.26 \pm 0.07$ a & $0.194 \pm 0.00$ a & 6 \\
$0.006 \%$ & $21.89 \pm 0.03$ b & $11.08 \pm 0.01$ a & $0.191 \pm 0.00$ a & 12 \\
$0.05 \% ;$ & $23.47 \pm 0.31$ c & $11.67 \pm 0.21$ b & $0.156 \pm 0.01$ b & 44 \\
$0.4 \%$ & $\overline{5,68}$ & $\overline{5,98}$ & $\overline{13,00}$ & 100 \\
C.V. $(\%)$ & & &
\end{tabular}

*Means followed by distinct letters in the same column differ in the Tukey test $(\mathrm{P}<0.05)$. 

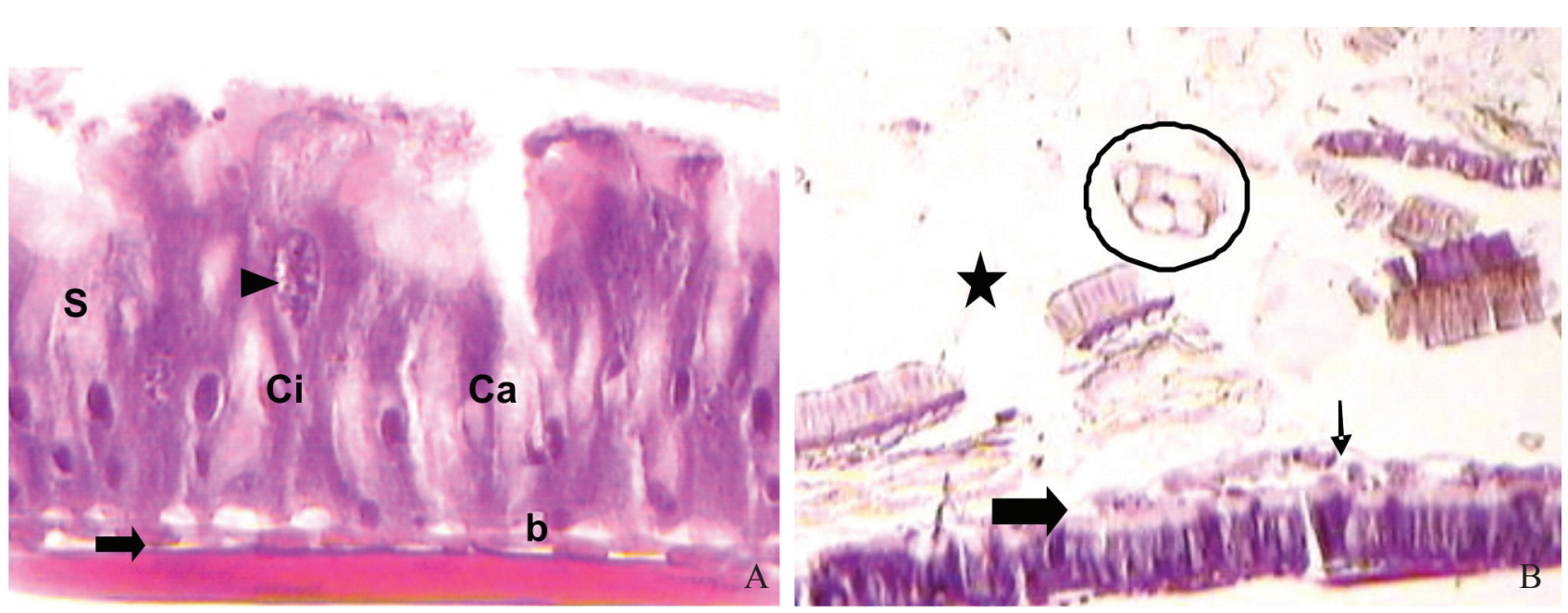

Fig. 1. Longitudinal histological slices of the midgut of S. frugiperda caterpillars on an artificical diet, stained using the Hematoxila- Eosina (HE) technique showing: (A) HE-400x stain: in the epithelial caliciform [Ca] cells there are regenerative cells [b]; secretion [s]; muscle fibres [arrow] and the nucleus of a normal columnar cell [arrowhead] and the cytoplasm [Ci]; (B) HE-100x : a general view of the digestibe tube showing the epithelial lining [large arrow], the peritrophic membrane [small arrow], bags [circle] and the lumen [star].

the control. This effect was highly accentuated at the $0.05 \%$ concentration level than at the $0.006 \%$ level (Table I).

For the pupal stage duration, only the neem oil concentration of $0.05 \%$ resulted in mortality significantly higher than the control. At the lowest concentration, $0.006 \%$ no significant difference was found in relation to the pupa developed from the caterpillars fed on diet without neem oil (Table I).

In terms of pupa weight, it was found that surviving the caterpillars treated with a concentration level of $0.05 \%$ caused a significant reduction in weight and, produced smaller adults (Table I).

Histological analysis. By observing the control group, it was found that the midgut lining consists of a pseudo-stratified epithelium, simple column type composed of four layers, with one layer covering the connective tissue membrane, two layers of muscular fiber and a single layer of epithelial cells resting on the base membrane. Beneath this, and separated by the ectoperitrophic space, the peritrophic matrix (PM) could be seen. The muscle layer maintains the same pattern along the whole length, although the external layer consists of longitudinal muscle and the internal layer has circular fibers. It was also noted that the muscle layer in this region is thinner than that in the foregut (Fig. 1).

The epithelium is composed of three distinct cell types: columnar cells, caliciform cells found between the columnar cells, and the regenerative or interstitial cells found in isolation or in groups at the base of the columnar and caliciform cells. The columnar cells form the largest cell group in the midgut. Their size depends on the quantity of food present and the peristalsis of the intestine wall. These cells have grooved edges, or microvilosities, responsible for increasing the surface area. Each cell has a central, oval nucleus and acidophilus cytoplasm; the caliciform cells have a distal opening and the
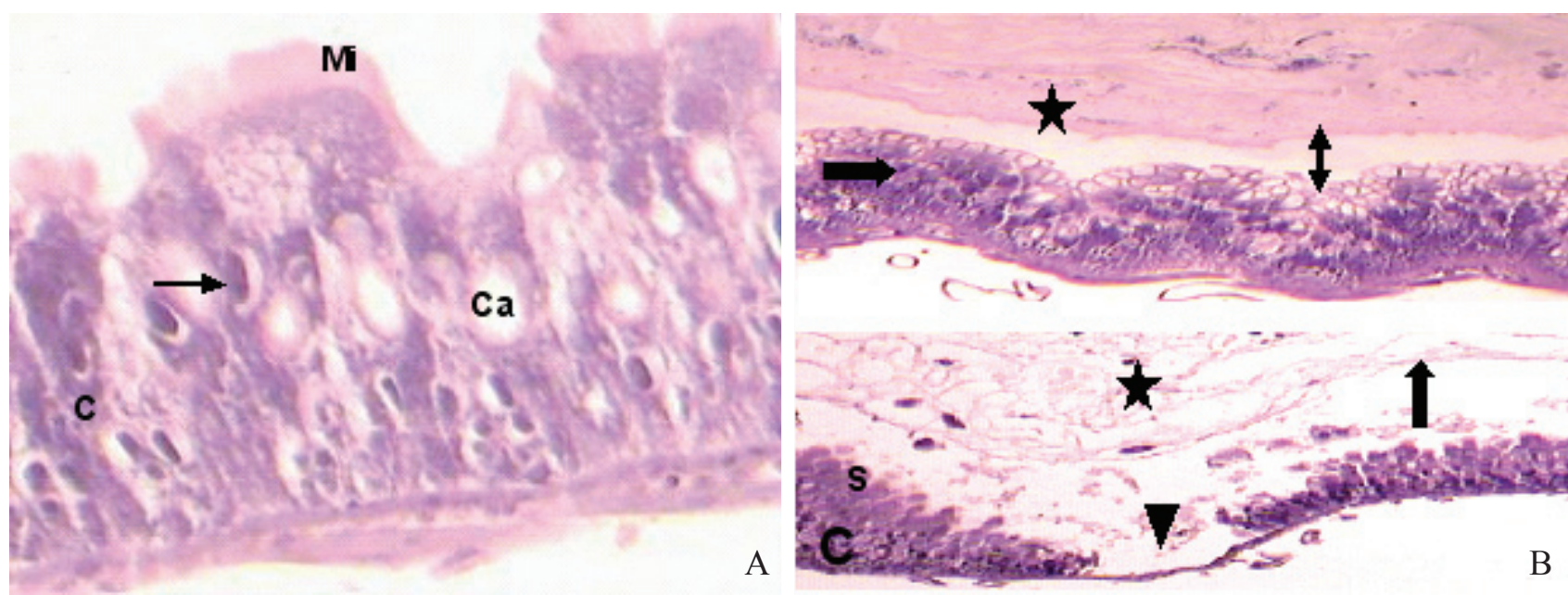

Fig. 2. Longitudinal histological slices of the midgut of $S$. frugiperda treated with $0.006 \%$ Neem oil stained with Hematoxila- Eosina(HE), showing: (A) HE400x: microvilosities [Mi], columnar cell [C] and nucleus [arrow]; (B) HE-100x: lumen [star], ectoperitrophic space [two-way arrow] and epithelium [thick arrow]; (C) HE-100x: loss of lining [arrowhead], secretion [S], peritrophic membrane [arrow] and lumen [star]. 
free edge has internal grooves with clear cytoplasm and a basal nucleus. The interstitial or regenerative cells seem to be the same origin as the columnar and caliciform lining cells. These cells are generally very small and triangular-shaped with basophilus cytoplasm, and a spherical, central nucleus (Fig. 1).

The peritrophic matrix (PM) of the midgut starts where the foregut joins the midgut epithelium and ends near the hindgut epithelium. This membrane is transparent and has different thickness along the length of the digestive tract and separates the food from the epithelial cells of the gut. It is not connected to the epithelium and there is a space between the two layers (the ectoperitrophic space) filled with secretions from the midgut cells, granules and secretion products synthesized by the epithelial cells and a solution extracted from the food material that was filtered by the PM (Fig. 1).

The group of S. frugiperda caterpillars fed with $0.006 \%$ neem oil, when compared to the control group, showed modifications in the midgut epithelium such as columnar, regenerative and caliciform cell necrosis. It was also noted stratification of the epithelium in some regions and loss of lining in others with dislocation of the peritrophic membrane away from the epithelial lining, increasing the ectoperitrophic space. Because of the stratification, the caliciform cells suffered flattening with an abundance of mucous secretion. On the other hand the columnar cells were thinner and longer with basophilus cytoplasm and a significant increase in microvilosities at some points of the lining. The nuclei of these cells had dense chromatin and were smaller. There was a loss of cytoplasm on the tube light in the apical region of the columnar cells (Fig. 2).

In the group of caterpillars treated with $0.05 \%$, much of the midgut lining was stratified and the columnar cells showed visible alterations mainly with the loss of apical cytoplasm. There were undulations and degradation of the peritrophic matrix and undulations in the midgut epithelial lining (Fig. 3). Meanwhile, tissue from caterpillars treated with $0.4 \%$ neem oil showed clear necrosis of the midgut epithelium and the columnar cells suffered great degradation. The peritrophic matrix was thickened, degraded and folded (Fig. 4).

On the diets with other concentration levels, 0.05 and $0.006 \%$, food ingestion caused alterations in the structure and morphology of the midgut lining (Figs. 2-3). In the insects treated with $0.4 \%$ neem oil, the peritrophic matrix was thickened, degraded and folded. There were undulations along the midgut causing flattening of the cells and an increase in microvilosities. The digestive tube at $0.4 \%$ concentration level was practically empty and was smaller and thinner (Figs. 4).

In the insect digestion systems there is a membrane composed of chitin, proteins (such as peritrophins) and proteoglycans, a peritrophic matrix layer that surrounds the food bolus with the function of offering chemical and mechanical protection as well as defense against pathogens (Terra 1996; Lehane 1997; Tellam et al. 1999).

The prolongation of the larval and pupal stages observed in sub-lethal doses, lower than $0.05 \%$ (Table I), there are effects of neem oil based products. Martinez \& Van Emden
(1999) reported the prolongation of the larval stage and feeding reduction caused by azadirachtin at sub-lethal concentrations when incorporated in artificial diets offered to $3^{\text {rd }}$ instar caterpillars of Spodoptera littoralis (Boisduval). The authors describe this secondary effect because of reduced food ingestion or due to the presence of inhibitors in the food or even due to inadequate feeding. The authors conclude that azadirachtin did not influence digestion efficiency but rather reduced the caterpillar's ability to convert ingested food into nutrients to growth. These secondary effects were evident in the pupa weight measurements where a weight reduction was found at $0.05 \%$ concentration compared $0.006 \%$ and with the control (Table I).

Neem effects on morphology were seen only on the mesenteron, depending on the time and concentration used, such as: epithelium, reduction on regenerative cells and on the secretory activity in this region, confirmed by the histochemistry in 0.5 and $1 \%$ neem concentrations (Correia et al. 2009).

Another property attributed to azadirachtin is alteration of insect behavior and physiology. Mordue \& Nisbet (2000) reported these effects: increased mortality, occurrence of abnormal and delayed ecdysis, repellence, metamorphosis interference, sterility and anatomic abnormalities, as well as feeding reduction and reduced growth due to direct effects and for secondary reasons (Martinez \& Van Emden 2001).

According to Mordue \& Nisbet (2000), the physiological effects of azadirachtin occur in two ways: directly on cells and tissue (Nasiruddin \& Mordue 1993), and indirectly through the endocrine system. As a direct effect, to azadirachtin is attributed the inhibition of cell division and protein synthesis. Both effects can be seen in muscle flaccidity, cell necrosis, loss of cell regeneration capacity and reduction in enzyme production.

In this study, alterations were found in the midgut of caterpillars submitted to sub-lethal doses with a consequent elongation of the life cycle and pupa weight reduction. This fact indicates that the neem product promotes morphology alterations and consequently affects nutrient absorption efficiency. The midgut, the intermediate section of the digestive tract where most of the digestion and food absorption occurs, has epithelial cells that produce enzymes and others that absorb the digested food (Borror \& Delong 1969).

Also at the $0.05 \%$ concentration, some caterpillars encountered difficulties in shedding the exuvia, which remained stuck to the body. There were also some deformed specimens at the end of the larval development with characteristics of both larva and pupa indicating incomplete metamorphosis. Calvez (1981) adds that the hormonal mechanism may be regulated by exogenous factors such as the amount of food ingested.

The $S$. frugiperda caterpillars fed on diet with neem oil showed histopathological alterations in the midgut region that varied in intensity according to the concentration level of neem. Being the midgut the main food digestion and absorption site, it is, therefore, the most vulnerable region to the action of foreign substances. However, prior to interaction with the epithelial cells, the elements encounter barriers: the 

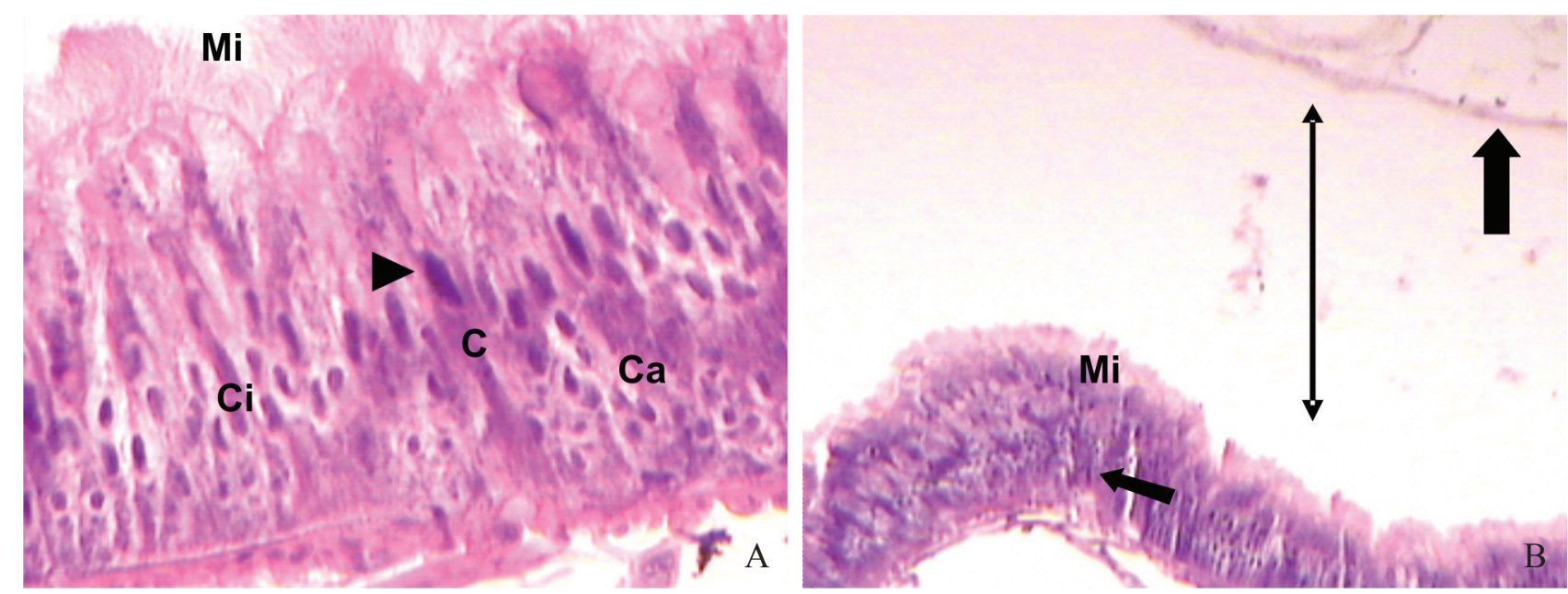

Fig. 3. Longitudinal histological slices of the midgut of S. frugiperda treated with $0.05 \%$ Neem oil stained with Hematoxila- Eosina(HE), showing: (A) HE400x: nucleus[arrowhead], columnar cell [C] and microvilosities [Mi]; (B) HE-100x: ectoperitrophic space [two-way arrow], peritrophic membrane [large arrow] and epithelial lining [small arrow].

peritrophic matrix and digestive juices (Barbehenn \& Martin 1995; Matos et al. 1999; Mohan et al. 2006).

In the treatment with concentration of 0.006 and $0.05 \%$, there was the presence of secretion vesicles and cytoplasm extrusion at the apex of the columnar cells and the dislocation of some cells with the lining secretion product. These effects have also been described to other insect species as Ephestia küehniella (Pyralidae) (Smith et al. 1969); Apis mellifera (Apidae) (Jimenez \& Gilliam 1990); Hyalophora cecropia (Saturniidae) (Anderson \& Harvey 1996), and Anticarsia gemmatalis (Noctuidae) (Levy et al. 2004; Knaak \& Fiuza 2005). These authors suggested that the phenomenon of cytoplasm loss is probably correlated to cell degeneration in epithelial renewal. These patterns occur due to high enzyme secretion activity in the midgut in an attempt to restore the lining that is being attacked (Terra \& Ferreira 1994; Cristofoletti et al. 2000; Levy et al. 2004).
Billingsley \& Lehane (1996) and Levy et al. (2004) report morphological aspects similar to those of S. frugiperda regenerative cells that are responsible for the process of lining cell recovery. It is believed that the midgut epithelial cells, when undergoing massive loss during digestion or in cases of necrosis, are replaced by mitotic activity from the regenerative cells. This cell renewal occurs due to the growth of the digestive tube at each moult, and to replace damaged cells, as well as an aiding defense mechanism against pathogens that infect these cells (Chiang et al. 1986).

The peritrophic matrix, at all concentration levels of neem oil, showed alterations such as degradation, thickening and fragmentation and a subsequent loss of defense capacity against the action of neem on the epithelium. The peritrophic matrix acts as a protective barrier against various chemical, physical and microbial food components (Peters 1992).

The data obtained from the biological and histological
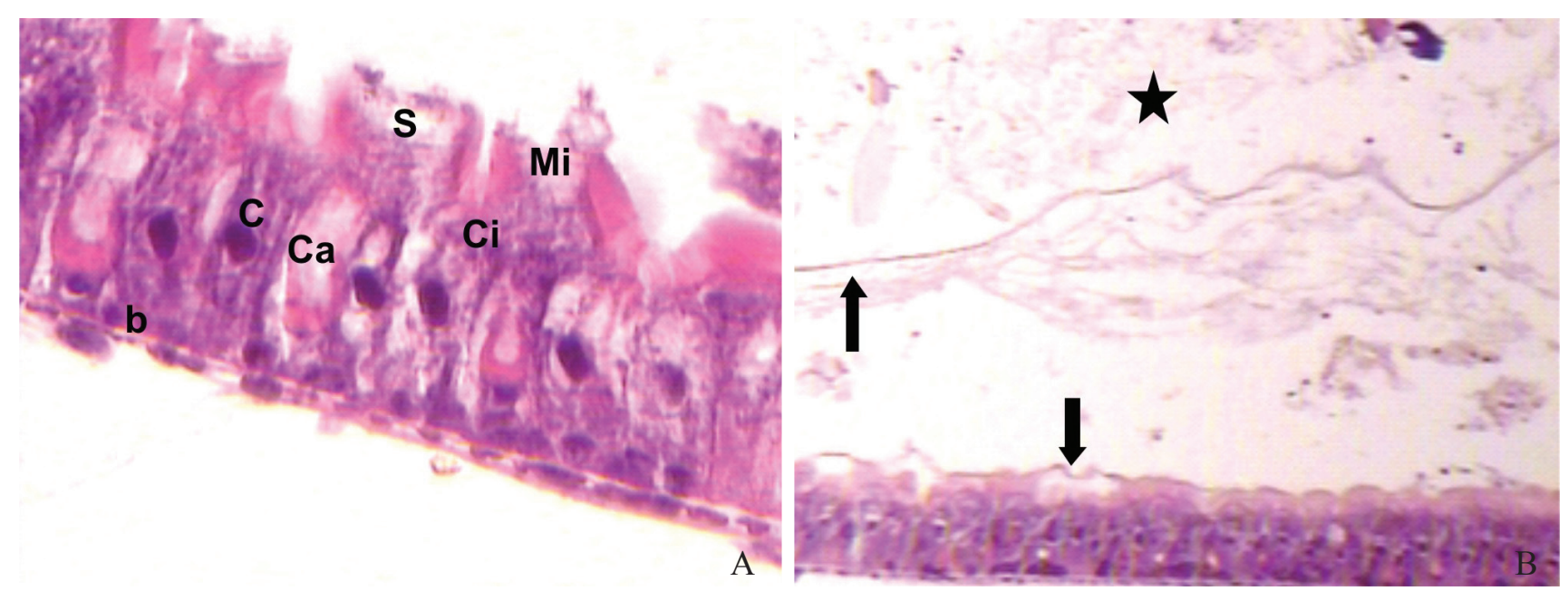

Fig. 4. Longitudinal histological slices of the midgut of S. frugiperda treated with $0.4 \%$ (A and B). Neem oil stained with Hematoxila- Eosina(HE), showing: (A) HE-400x: microvilosities [Mi], columnar cell [C], caliciform cell [Ca], nucleus [arrowhead], cytoplasm [Ci] and regenerative cell [b]; (B) HE-100x: lumen [star] and peritrophic membrane [arrows]. 
observations indicated the diverse action of lethal sub-doses of neem oil on insects, physiological effects as shown in the midgut histopathology. Also, its action reflected on the insect development causing alterations to larval and pupal stage duration as well as reduction of pupa weight reduction and an increasing death rate, which is function of the neem oil concentration level.

Acknowledgements. To the Ministry of Science and Technology (MCT); Pantanal Research Centre (CPP); and the Mato Grosso do Sul Support Foundation for the Development of Teaching, Science and Technology (FUNDECT), for financial support.

\section{REFERENCES}

Anderson, E. \& W. R. Harvey. 1966. Active transport by the Cecropia midgut: II. Fine structure of the midgut epithelium. Journal of Cell Biology 31: 107-134.

Barbehenn, R. V. \& M. M. Martin. 1995. Peritrophic envelope permeability in herbivorous insects. Journal of Insect Physiology 41: 303-311.

Barreto, C. F.; G. M. Cavasin; H. H. G. Silva \& I. G. Silva. 2006. Study of the morphohistological modifications in larvae of Aedes aegypti (Diptera, Culicidae) submitted to the pure ethanolic extract of Sapindus saponaria Lin. (Sapindaceae). Revista de Patologia Tropical 35: 37-57.

Billingsley, P. F. \& M. J. Lehane. 1996. Structure and ultrastructure of the insect midgut. p. 3-30. In: M. J. Lehane \& P. F. Billingsley. (eds.) Biology of the insect midgut. London, Chapman and Hall, $486 \mathrm{p}$.

Borror, D. J. \& D. M. Delong. 1969. Introdução ao estudo dos insetos. São Paulo, Edgard Blucher Ltda, $653 \mathrm{p}$.

Buzzi, Z. J. 2002. Entomologia Didática. $3^{\text {a }}$ ed., Curitiba, editora UFPR, $306 \mathrm{p}$.

Calvez, B. 1981. Progress of developmental programme during the last larval instar of Bombyx mori: relationships with food intake, ecdysteroids and juvenile hormone. Journal of Insect Physiology 27: 233-239.

Cavalcante, V. M. \& C. Cruz-Landim. 1999. Types of cells present in the midgut of the insects: A review. Naturalia 24: 19-40.

Chiang, A. S.; D. F. Yen \& W. K. Peng. 1986. Defense reaction of midgut epithelial cells in the rice moth larva (Corcyra cephalonica) infected with Bacillus thuringiensis. Journal of Invertebrate Pathology 47: 333-339.

Correia, A. A.; W. Wanderley-Teixeira; A. A. C. Teixeira; J. V. de Oliveira \& J. B. Torres. 2009. Morphology of the Alimentary Canal of Spodoptera frugiperda (J E Smith) Larvae (Lepidoptera: Noctuidae) Fed on NeemTreated Leaves. Neotropical Entomology 38: 83-91.

Cristofoletti, P. T.; A. F. Ribeiro \& W. T. Terra. 2000. Apocrine secretion of amylase, exocytosis of trypsin along the midgut of Tenebrio molitor larvae. Journal of Insect Physiology 47: 143-155.

Dequech, S. T. B.; L. M. Fiuza; R. F. P. Silva \& R. C. Zumba. 2007. Histopathology of larvae of Spodoptera frugiperda (Lep., Noctuidae) infected by Bacillus thuringiensis aizawai and with eggs of Campoletis flavicincta (Hym., Ichneumonidae). Ciência Rural 37: 273-276.

Greene, G. L.; N. C. Lepla \& W. A. Dickerson. 1976. Velvetbean caterpillar: a rearing procedure and artificial medium. Journal of Economic Entomology 69: 488-497.

Jimenez, D. R. \& M. Gilliam. 1990. Ultrastructure of the ventriculus of the honey bee, Apis mellifera (L.): cytochemical localization of acid phosphatase, alkaline phosphatase, and nonspecific esterase. Journal Cell and Tissue Research 261: 431-443.

Knaak, N. \& L. M. Fiuza. 2005. Histopathology of Anticarsa gemmatalis Hübner (Lepidoptera: Noctuidae) treated with nucleopolyhedrovirus and Bacillus thuringiensis serovar Kurstaki. Brazilian Journal of Microbiology 36: 196-200.

Lehane, M. J. 1997. Peritrophic matrix structure and function. Annual Review of Entomology 42: 525-550.
Levy, S. M.; A. M. F. Falleiros; E. A. Gregório; N. R. Arrbola \& L. A. Toledo. 2004. The Larval Midgut of Anticarsia gemmatalis (Hübner) (Lepidoptera: Noctuidae): Light and electron microscopy studies of the epithelial cells. Brazilian Journal of Biology 64: 633-638.

Luna, L. G. 1968. Manual of histologic staining methods of the Armed Forces Institute of Pathology. New York, McGraw-Hill, $258 \mathrm{p}$.

Maredia, K. M.; O. L. Segura \& J. A. Mihm. 1992. Effects of neem, Azadirachta indica, on six species of maize insect pests. Tropical Pest Management 38: 190-195.

Martinez, S. S. 2002. O Neem - Azadirachta indica Natureza, Usos Múltiplos, Produção. Londrina, IAPAR, $142 \mathrm{p}$.

Martinez, S. S. \& H. F. Van Emden. 1999. Sublethal concentrations of azadirachtin affect food intake, conversion efficiency and feeding behaviour of Spodoptera littoralis (Lepidoptera: Noctuidae). Bulletin of Entomological Research 89: 65-71.

Martinez, S. S. \& H. F. Van Emden. 2001. Growth disruption, abnormalities and mortality of Spodoptera littoralis caused by azadirachtin. Neotropical Entomology 30: 113-125.

Matos, T. G. T.; L. G. Giugliano; M. R. Bergmann \& S. N. Báo. 1999. Structural and ultrastructural studies of Anticarsia gemmatalis midgut cells infected with the baculovirus $A$. gemmatalis nucleopolyhedrovirus. International Journal of Insect Morphology and Embryology 28 195-201.

Michalany, J. 1980. Técnica histológica em anatomia patológica. $1^{a}$ ed., São Paulo, Ed. Pedagógica e Universitária Ltda, 277 p.

Mohan, S.; P. W. K. Ma; T. Pechan; E. R. Bassford; W. P. Williams \& D. S. Luthe. 2006. Degradation of the $S$. frugiperda peritrophic matrix by an inducible maize cysteine protease. Journal of Insect Physiology 52: $21-28$.

Mordue (Lutz), A. J. \& A. Nisbet, 2000. Azadirachtin from the Neem Tree Azadirachta indica: its Action Against Insects. Anais da Sociedade Entomológica do Brasil 29: 615-632.

Mossini, S. A. G. \& C. Kemmelmeir. 2005. A árvore Neem (Azadirachta indica A. Juss): Múltiplos usos. Acta Farmaceutica Bonaerense 24 $139-48$.

Nasiruddin, M. \& A. J. Mordue (Luntz). 1993. The effect of azadirachtin on the midgut histology of the locusts, Schistocerca gregaria and Locusta migratoria. Tissue Cell 25: 875-884.

Pearse, A. G. E. 1968. Histochemistry: theoretical and applied. 2ed., Edinburgh, C. Livingstone, 998 p.

Peters, W. 1992. Peritrophic membrane. p. 87-101. In: S. D. Bradshaw; W. Burggren; H. C. Heller; S. Ishii; H. Langer; G. Neuweiler \& D. J. Randall (eds), Zoophysiology 30, Berlin, Springer-Verlag, 238 p.

Prates, H. T.; P. A. Viana \& J. M. Waquil. 2003. Activity of neem tree (Azadirachta indica) leaves aqueous extract on Spodoptera frugiperda. Pesquisa Agropecuária Brasileira 38: 437-439.

Smith, D. S.; K. Compher; M. Janners; C. Lipton \& L. W. Wittle. 1969. Cellular organization and ferritin uptakein the mid-gut epithelium of a moth Ephestia kühniella. Journal of Morphology 127: 41-72.

Tellam, R. L.; G. Wijffels \& P. Willadsen. 1999. Peritrophic matrix proteins. Insect Biochemistry and Molecular Biology 29: 87-101.

Terra, W. R. 1996. Evolution and function of insect peritrophic membrane. Ciência e Cultura 48: 317-324.

Terra, W. R. \& C. Ferreira. 1994. Insect digestive enzymes: properties, compartmentalization and function. Comparative Biochemistry and Physiology 109: 1-62.

Vendramim, J. D. \& E. Castiglioni. 2000. Aleloquímicos, resistência de plantas e plantas inseticidas. p. 113-128. In: Guedes, J.C.; Costa, I.D. \& Castiglioni (Org.). Bases e técnicas do manejo de insetos. Santa Maria, UFSM/CCR/DFS, $234 \mathrm{p}$.

Viana, P. A. \& H. T. Prates. 2003. Larval development and mortality of Spodoptera frugiperda fed on corn leaves treated with aqueous extract from Azadirachta indica leaves. Bragantia 62: 69-74.

Waquil, J. M.; F. M. F. Villela \& J. E. Foster. 2002. Resistência do milho (Zea mays L.) transgênico (Bt) à Lagarta-do-cartucho, Spodoptera frugiperda (Smith) (Lepidoptera: Noctuidae). Revista Brasileira de Milho e Sorgo 1: $1-11$. 